\title{
Life history of Adalia bipunctata (Coleoptera: Coccinellidae) in Japan
}

\author{
Yasuruki SAKURATANI, Yoshmito MATSUMOTO, Motoki OKA, TaKahro KUBO, Atsushi FUJII, Minatsu \\ UOTANI and TORU TERAGUCHI
}

Entomological Laboratory, Faculty of Agriculture, Kinki University, Nara 631-8505, Japan

Key words. Adalia bipunctata, Harmonia axyridis, ladybird, univoltine, life history, immigrant, intraguild predation, Japan

\begin{abstract}
Adalia bipunctata is a well-known predaceous ladybird distributed in Europe, Central Asia and North America. This species has not been recorded in Japan. Recently, we found this species in the Osaka Bay area in central Japan, and assume that it was imported with goods such as timber by ships. We studied the life history and the distribution in the Osaka Bay area since the initial discovery. The larvae and adults preyed on aphids (mainly, Periphyllus viridis) on trees such as Acer buergerianum and Rhaphiolepis umbellata. The over-wintered adults appeared in March and laid eggs. The adults emerged in spring, and were in the rolled leaves throughout the rest of the year. Thus, in Japan this ladybird is univoltine with long inactivity in adult. The life history of Japanese population of $A$. bipunctata differs considerably from other areas where populations are multivoltine. The developmental threshold was estimated to be $6.3^{\circ} \mathrm{C}$ and the sum of effective temperatures was 322.6 day-degrees for the period from egg to adult emergence. Predation on prepupae of $A$. bipunctata by the larvae of native species such as Harmonia axyridis was observed occasionally.
\end{abstract}

\section{INTRODUCTION}

The two-spot ladybird, Adalia bipunctata (L.) is distributed in central Asia, Europe and North America (Hodek, 1973; Hodek \& Honěk, 1996). Similar to Coccinella septempunctata L., A. bipunctata is an important predator of aphids in Europe.

This ladybird had not been reported from Japan, although ten ladybird species (most of them may be immigrants) were recently recorded (Sasaji, 1992). We first discovered one $A$. bipunctata adult on 16th December 1993 in Osaka Bay area, Japan (Sakuratani, 1994). This adult overwintered under the bark of a dead tree in a park. The following spring active individuals of $A$. bipunctata were observed in the park.

Recently, several predaceous coccinellid species, for example Harmonia axyridis (Pallas) and C. septempunctata were introduced to Europe or North America,respectively (e.g.; Tedders \& Schaefer, 1994). They are competing there with the native species such as $A$. bipunctata.

We are investigating the life history, population dynamics and the inter-species relationships of $A$. bipunctata with the native coccinellid species in Japan. In this paper, we report on the life history in Japan.

\section{MATERIALS AND METHODS}

\section{Field observations}

The seasonal occurrence of the developmental stages of $A$. bipunctata was observed in the Central Park of Osaka Nanko $\left(34.6^{\circ} \mathrm{N}, 135.4^{\circ} \mathrm{E}\right.$; alt. $5 \mathrm{~m}$ a.s.1.; area of $\left.25 \mathrm{ha}\right)$ Osaka City, Osaka Pref., Japan, from 1996 to 1999. The census was carried out on trees such as maple, Acer buergerianum Miquel and grasses applying a transect method 1-4 times per month or season. The presence and behavior of native ladybirds on these plants were also recorded. The number of adults aestivating and overwintering was checked in each site.

\section{Laboratory study}

Progenies from several A. bipunctata females were reared under four constant temperatures of $15 \pm 1,20 \pm 1,25 \pm 1$ and $30 \pm 1{ }^{\circ} \mathrm{C}$, the relative humidity of about $70 \%$, and a photoperiod of 14L : 10D. Several aphid species, mainly Periphyllus viridis
(Matsumura) infesting a maple tree, $A$. buergerianum, were fed to larvae and adults. The developmental zero and the sum of effective temperatures were calculated.

\section{RESULTS}

\section{Field observations}

The percentages of each developmental stage found in four years are shown in Fig. 1. The eggs are not included, because it was difficult to distinguish them from those of native coccinellid species such as Menochilus sexmaculatus (F.). Mating and oviposition of $A$. bipunctata was observed in late March and April in each year. Egg masses were found only in spring. Larvae appeared from mid April to late May. They preyed on aphids, $P$. viridis on $A$. buergerianum, and other aphids infesting shrubs such as Rhaphiolepis umbellata Makino and Hibiscus syriacus $\mathbf{L}$.

Pupae were found attached to leaves of maple, $R$. umbellata and other trees during May and early June, and often aggregated on leaf (Fig.2). In spite of aggregations, cannibalism to prepupae or pupae by the larvae or adults of $A$. bipunctata was not found, although we looked for it. However, on the several trees the larvae of $H$. axyridis preyed often on the prepupae or pupae of $A$. bipunctata in each year (Fig. 3).

The newly emerged adults were observed each year in early May preying on aphids on the maple and other trees. They appeared to enter aestivation in mid June. They were dormant in "webs" made by spiders or caterpillars or between overlapped leaves or in rolled leaves of maple, evergreen oak and other trees (Fig. 4). There were one to ten aestivating adults in one site.

Adult $A$. bipunctata was inactive through the summer, but some adults preyed on aphids in autumn. However, no eggs or larvae were observed during the summer and autumn. The adults apparently entered aestivation and hibernation diapause. The overwintering sites were in the webs on evergreen oak, like in aestivation, but some individuals were found under the bark of live $A$. buergerianum. Some inactive adults in the webs observed at a census time were not found next time (after sev- 

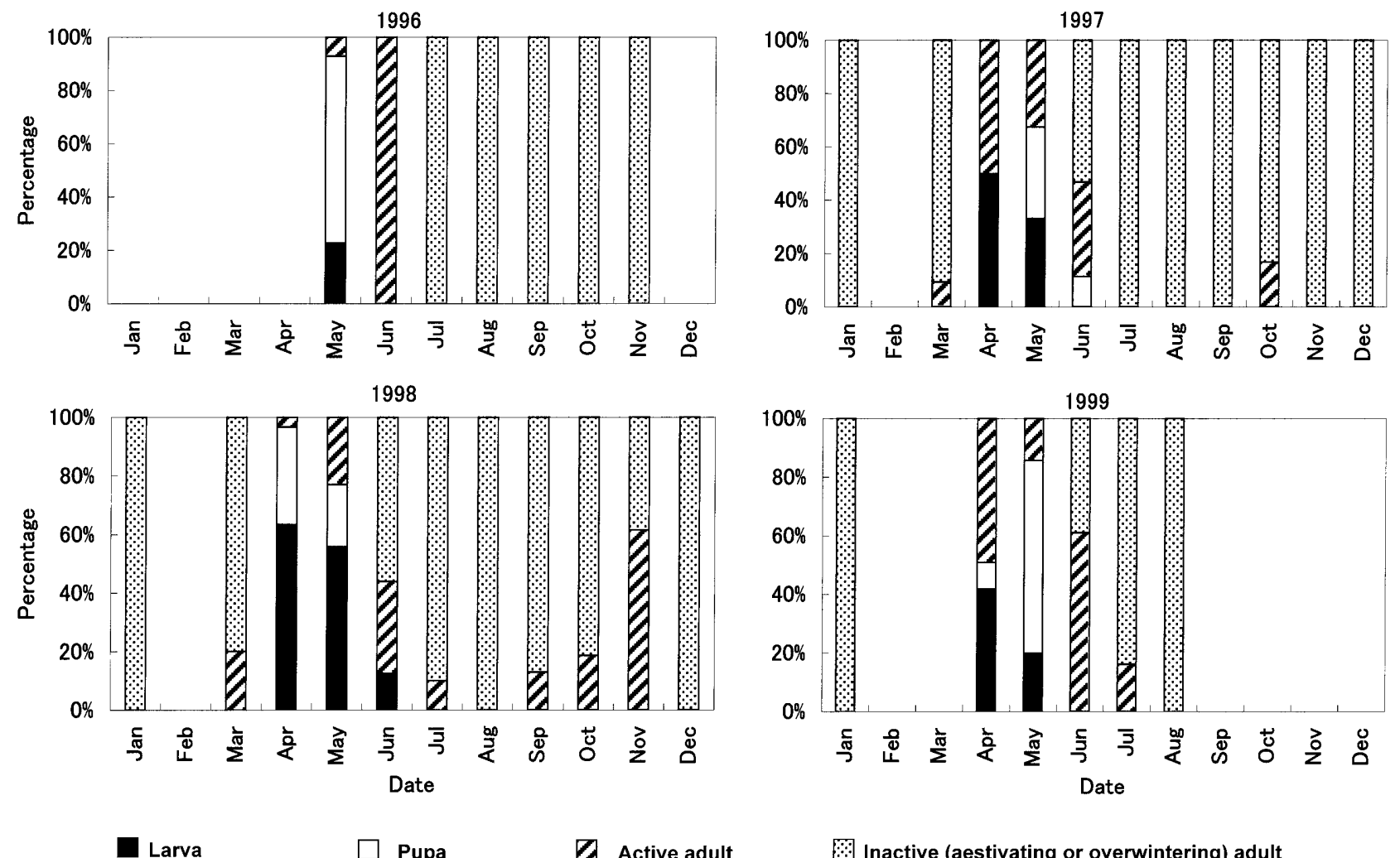

$\square$ Pupa

$\square$ Active adult

Inactive (aestivating or overwintering) adult

Fig.1. Seasonal changes of percentage of developmental stages of Adalia bipunctata in Japan, based on the relative abundance in the transect census. Eggs are not shown because of the difficulty of identification.

eral weeks); apparently due to our disturbance adults moved to other sites.

In Japan, the dark forms (Hodek \& Honěk, 1996) of adult of this ladybird were very rare (less than $1 \%$ ), and almost all were the typical two-spot form in each year.

\section{Developmental period}

Figure 5 shows the developmental periods under four constant temperatures. The developmental zero was $8.2,4.8,7.5,6.3^{\circ} \mathrm{C}$ for egg, larva, pupa and egg-adult emergence, respectively

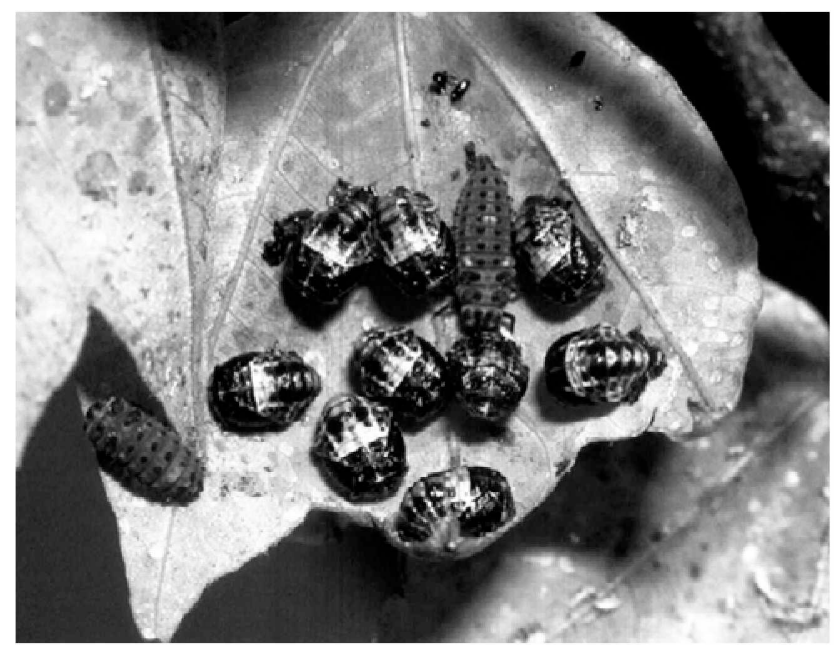

Fig. 2. Aggregation of pupae of $A$. bipunctata attached on a maple leaf.
(Table 1). The sum of effective temperatures was 43.9, 192.3, 86.2, 322.6 day-degrees, for egg, larva, pupa and the period from egg to adult emergence, respectively (Table 1). No females laid eggs at 15 and $30^{\circ} \mathrm{C}$. The preoviposition periods were 24.6 days at $20^{\circ} \mathrm{C}$ and 29.9 days at $25^{\circ} \mathrm{C}$.

\section{DISCUSSION}

In Osaka City, Japan, A. bipunctata is univoltine with spring breeding. Immature stages and newly eclosed adults are only observed in the spring. The adults are inactive from summer to

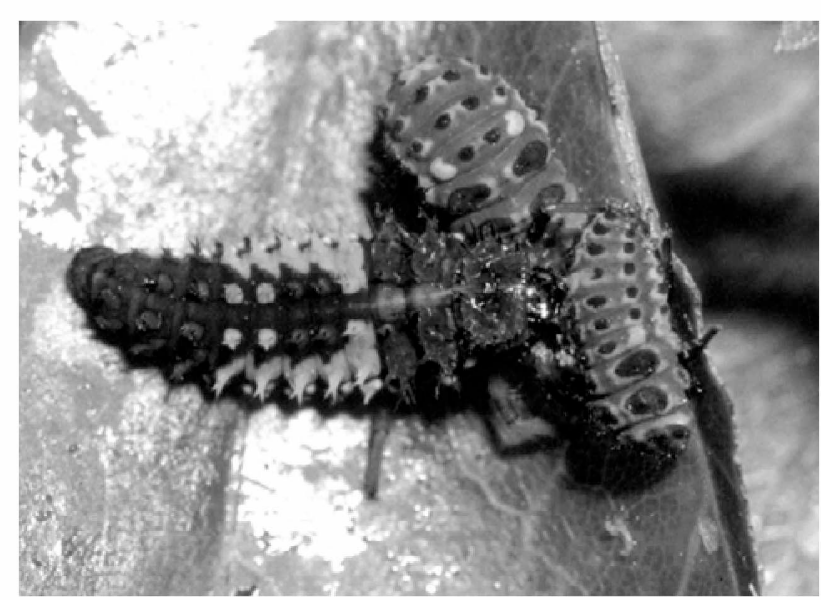

Fig. 3. Predation on prepupa of $A$. bipunctata by a larva of native ladybird, Harmonia axyridis. 


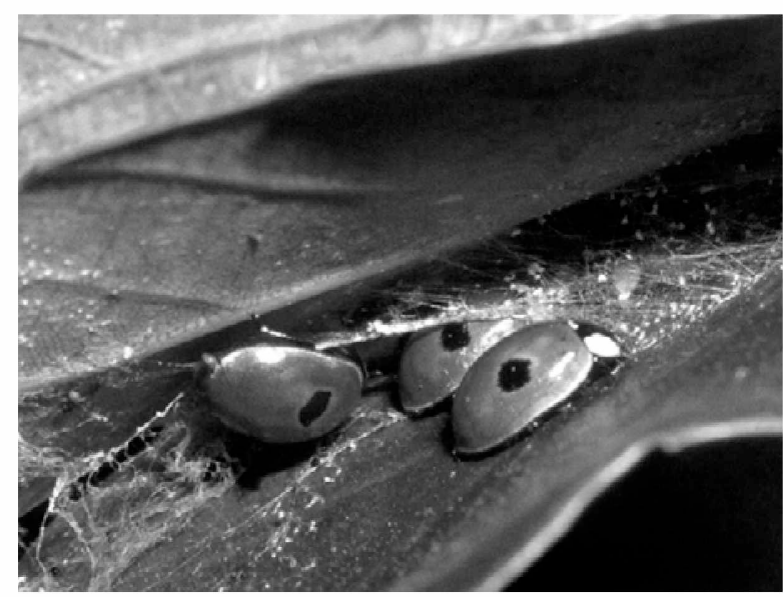

Fig. 4. Inactive adults of $A$. bipunctata aestivating in the leaf with web made by spider.

next spring, though some adults actively fed in the autumn but did not reproduce. The life history type of $A$. bipunctata in Japan is aestivo-hibernation (Hagen, 1962). In North America and Eurasia, this ladybird is typically multivoltine (Hodek \& Honěk, 1996), though in Finland it is univoltine with summer breeding (Hämäläinen, 1976).

This ladybird was first discovered in Japan near an international harbor. This species overwinters in aggregations under the bark of the wood and other sites (Hemptinne,1985; Hodek \& Honěk, 1996). A. bipunctata may have been introduced in winter with logs, but the original distribution area cannot be
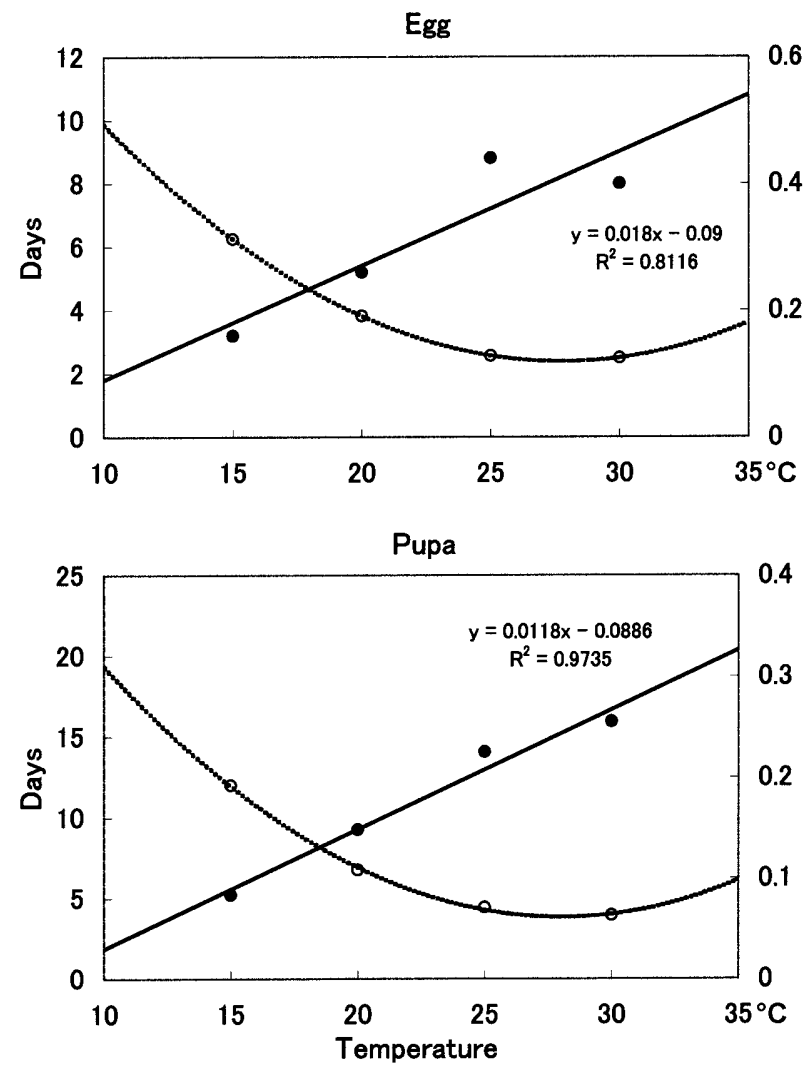

TABLE 1. Developmental threshold (to) and total effective temperature (K) in Japanese population of Adalia bipunctata.

\begin{tabular}{lcc}
\hline Stage & to $\left({ }^{\circ} \mathrm{C}\right)$ & $\mathrm{K}$ (day-degrees) \\
\hline Egg & 8.2 & 43.9 \\
Larva & 4.8 & 192.3 \\
Pupa & 7.5 & 86.2 \\
Egg-Adult* & 6.3 & 322.6 \\
\hline
\end{tabular}

* Excluding the preoviposition period

determined. The distribution of this ladybird has not yet spread over Japan; still it has been found only in the Central Park of Osaka Nanko (area of 25 ha), Osaka City.

The number of individuals fluctuated among years, and some individuals were attacked by native coccinellids, especially $H$. axyridis. However, A. bipunctata bred continuously for the six years of the study. In North America or Europe, H. axyridis or C. septempunctata were introduced to control aphids and many studies on these species were carried out (e.g.; Tedders \& Schaefer, 1994; Coderre et al., 1995; Dreistadt et al.,1995; Kidd \& Nalepa, 1995; Phoofolo \& Obrycki, 1995). The number of $H$. axyridis increased every year, and causes strong competition with native species (Horn, 1999). In Japan, prepupae and pupae of $A$. bipunctata were often eaten by the larvae of native species such as $H$. axyridis. The developmental zero of $A$. bipunctata is $6.3^{\circ} \mathrm{C}$ and the sum of effective temperatures is 322.6 daydegrees for the period from egg to adult emergence. These values are smaller than those of $H$. axyridis (Kawauchi, 1979). In Japan both species start breeding in spring.

In each year $A$. bipunctata was in the prepupal or pupal stage, when $H$. axyridis was in larval stage. On the same trees the pre-
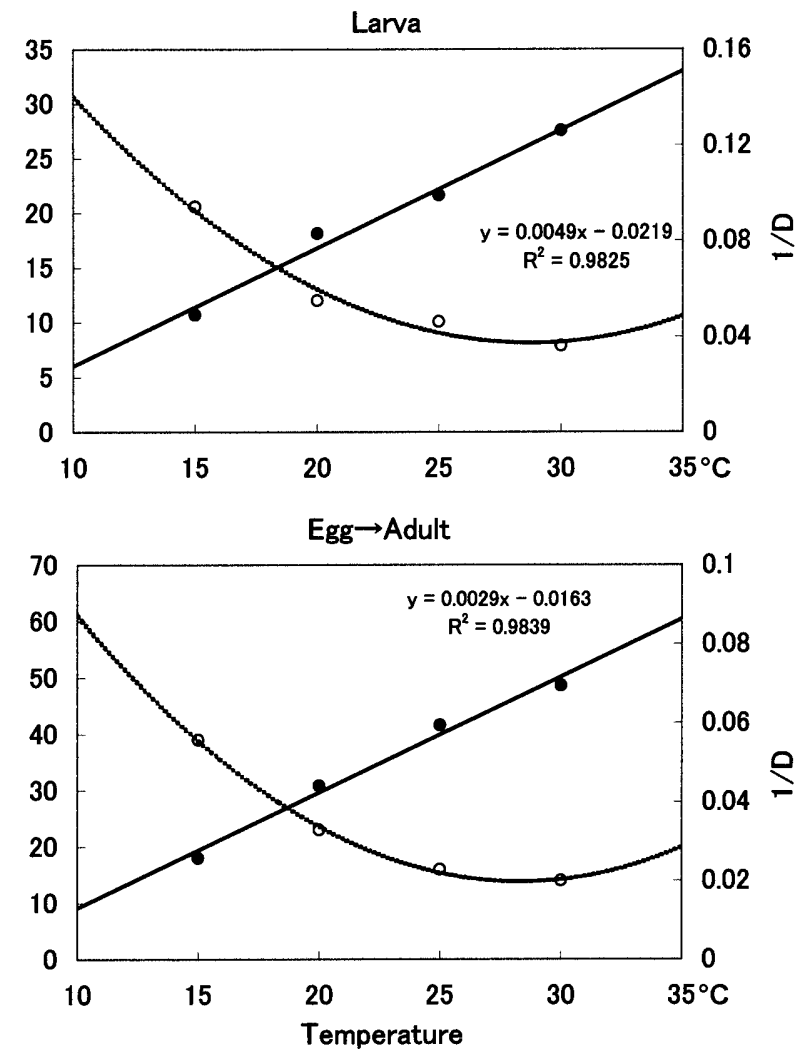

Fig. 5. Relationships between temperature and developmental period $(O)$ or rate of development, 1/D [D : developmental period (day)] 
pupae and pupae of $A$. bipunctata might thus be attacked by the larvae of $H$. axyridis.

In future, in $A$. bipunctata, inter-relationships with native species, the population trend, the spreading of distribution, and the melanism in relation to climate and industrialization (Mikkola \& Albrecht, 1988) need to be investigated in Japan.

ACKNOWLEDGEMENTS. We thank S. Takahashi of Utsunomiya University for his kindness in identification of the aphid species, and T. Sugimoto of Kinki University for his encouragement and advices.

\section{REFERENCES}

Coderre D., Lucas E. \& GaGne I. 1995: The occurrence of Harmonia axyridis (Pallas) (Coleoptera: Coccinellidae) in Canada. Can. Entomol. 127: 609-611.

Dreistadt S.H., Hagen K.S. \& Bezark L.G. 1995: Harmonia axyridis (Pallas) (Coleoptera:Coccinellidae), first Western United State record for this Asiatic lady beetle. Pan-Pacif. Entomol. 71: 135-136.

HaGen K.S. 1962: Biology and ecology of predaceous Coccinellidae. Annu. Rev. Entomol. 7: 289-326.

HÄMÄLÄINEN M. 1976: Rearing the univoltine ladybeetles, Coccinella septempunctata and Adalia bipunctata (Col., Coccinellidae), all year around in the laboratory. Ann. Agric. Fenn. 15: 66-71.

Hemptinne J.-L. 1985: Les sites d'hivernation de la coccinelle Adalia bipunctata (L.) (Col., Coccinellidae) en Belgique. Acta Ecol. Ecol. Appl. 6(1): 3-13.
Hodek I. 1973: Biology of Coccinellidae. Academia, Prague \& Dr W. Junk, The Hague, 260 pp.

HODEK I. \& HONĚK A. 1996: Ecology of Coccinellidae. Kluwer Academic Publishers, Dordrecht, 464 pp.

HoRN D.J. 1999: Impact of Harmonia axyridis in Ohio. Aphidophaga VII, Abstract. Bromont, Canada, 42 pp.

KaWAUCHI S. 1979: Effects of temperatures on the aphidophagous coccinellids. Kurume Univ. J. 28: 47-51 (in Japanese).

KiDD K.A. \& NalePA C.A. 1995: Distribution of Harmonia axyridis (Pallas) (Coleoptera: Coccinellidae) in North Carolina and Virginia. Proc. Entomol. Soc. Wash. 97(3): 729-731.

Mikkola K. \& Albrecht A. 1988: The melanism of Adalia bipunctata around the Gulf of Finland as an industrial phenomenon (Coleoptera, Coccinellidae). Ann. Zool. Fenn. 25 : 177-185.

Phoofolo M.W. \& ObrYcki J.J. 1995: Comparative life-history studies of Nearctic and Palearctic populations of Coccinella septempunctata (Coleoptera: Coccinellidae). Envir. Entomol. 24: $581-587$.

SaKuRatani Y. 1994: New record of Adalia bipunctata (Linnaeus) (Coleoptera, Coccinellidae) from Japan. Jap. J. Entomol. 62: 627-628.

SASAII H. 1992: The recently new recorded ladybirds from Japan (Coccinellidae). Coleopt. News 100: 10-13 (in Japanese).

Tedders W.L. \& Schaefer P.W. 1994: Release and establishment of Harmonia axyridis (Coleoptera: Coccinellidae) in the Southeastern United States. Entomol. News 105: 228-243.

Received January 6, 2000; accepted August 20, 2000 